\title{
Pengaruh Waktu terhadap Efisiensi Dye-Sensitized Solar Cell (DSSC)
}

\author{
Sistha Ridha Alfidharisti, Fahru Nurosyid", dan Yofentina Iriani \\ Program Studi Fisika, Fakultas MIPA, Universitas Sebelas Maret, Surakarta \\ *Email: nurosyid@yahoo.com
}

\begin{abstract}
This study reported the influence of times on the efficiency of Dye-Sensitized Solar Cell (DSSC). The electrode spacings of DSSC were varied by two variations, $76 \mu \mathrm{m}$ and $114 \mu \mathrm{m}$. The DSSC was characterized using Keithley I-V Meter for over twenty-one days with changing over seven days to know the stability of DSSC. DSSC with electrode spacing of $76 \mu \mathrm{m}$ was stable for seven days with efficiency of $0.0347 \%$. The spacings of $114 \mu \mathrm{m}$ was stable for fourteen days with efficiency of $0.0117 \%$.
\end{abstract}

Keywords: DSSC, electrode spacing, I-V characterization, efficiency, stability

\begin{abstract}
ABSTRAK
Penelitian ini mengkaji pengaruh waktu terhadap effisiensi Dye Sensitized Solar Cell (DSSC). Jarak elektroda divariasi sebesar $76 \mu \mathrm{m}$ dan $114 \mu \mathrm{m}$. Karakterisasi sifat listrik menggunakan Keithley I-V meter yang dilakukan selama 21 hari dengan selang 7 hari untuk mengetahui kestabilannya. Karakterisasi $I-V$ dengan selang waktu pengukuran menunjukkan bahwa DSSC dengan jarak elektroda $76 \mu \mathrm{m}$ stabil hingga hari ke-7 dengan efisiensi 0,0347\%. Pada jarak $114 \mu \mathrm{m}$ stabil hingga hari ke-14 dengan efisiensi $0,0117 \%$.
\end{abstract}

Kata kunci: DSSC, jarak elektroda, karakterisasi $I$ - $V$, efisiensi, kestabilan

\section{PENDAHULUAN}

Teknologi sel surya banyak menarik perhatian karena kemampuannya dalam mengubah energi matahari menjadi energi listrik tanpa menyebabkan polusi lingkungan ${ }^{[1]}$. Sel surya yang sering digunakan saat ini adalah sel surya generasi pertama yaitu yang terbuat dari bahan silikon. Penggunaan sel surya ini masih relatif mahal karena pembuatannya yang menggunakan suhu tinggi dan proses vakum ${ }^{[2]}$. Penelitian sel surya terus berkembang seiring dengan berjalannya waktu, salah satunya penemuan Dye-Sensitized Solar Cell (DSSC) pada tahun 1991 oleh O'Reagen dan Gratzel. DSSC merupakan sel surya generasi ketiga, dimana pada sel surya ini tersensitasi dye atau zat warna ${ }^{[3-5]}$. Sejak penemuannya pada tahun 1991, DSSC banyak menarik perhatian karena biaya pembuatannya yang murah, teknik fabrikasinya sederhana, dan ramah lingkungan ${ }^{[6-7]}$. Efisiensi sel surya merupakan hal yang paling penting untuk mengetahui kemampuannya dalam mengkonversi cahaya menjadi energi listrik. Walaupun efisiensi yang dihasilkan DSSC masih relatif lebih kecil dibandingkan dengan sel surya silikon, banyak potensi yang masih bisa dikembangkan untuk meningkatkan efisiensinya ${ }^{[8]}$.

DSSC terdiri dari substrat Transparent Conductive Oxide (TCO) sebagai elektroda kerja dan elektroda lawan. Elektroda kerja terdiri dari lapisan semikonduktor yang dideposisi pada sisi konduktif kaca TCO, sedangkan katalis dideposisi pada kaca TCO yang lain sebagai elektroda lawan. Dye diadsorpsi oleh lapisan semikonduktor sebagai photosensitizer. Kedua elektroda digabungkan dengan jarak elektroda tertentu dengan struktur sandwich, kemudian diisi larutan elektrolit sebagai media transport elektron ${ }^{[9-10]}$. 
Beberapa penelitian telah dilakukan untuk meningkatkan efisiensi DSSC, salah satunya adalah optimasi larutan elektrolit. Grup penelitian Gratzel mengatakan bahwa salah satu kesulitan untuk mempertahankan kestabilan DSSC adalah dekomposisi elektrolit ${ }^{[11] .}$ Optimasi larutan elektrolit dapat dilakukan dengan cara optimasi jarak elektroda DSSC. Jarak elektroda mempengaruhi jumlah larutan elektrolit yang diberikan. Semakin besar jarak elektroda maka semakin banyak pula larutan elektrolit yang diberikan, begitupun sebaliknya. Larutan elektrolit akan terus berkurang seiring dengan berjalannya waktu sehingga mempengaruhi kestabilan DSSC.

Larutan elektrolit yang sering digunakan terdiri dari pasangan redoks dari $\mathrm{I}^{-}$dan $\mathrm{I}_{3}{ }^{-}$. Triiodide mereduksi kembali menjadi iodide oleh elektron dari rangkaian luar dan menggantikan elektron yang tereksitasi pada $d y e^{[12]}$. Pemberian elektrolit yang berlebihan pada DSSC, akan menyebabkan degradasi pada dye sehingga mengurangi performa DSSC [5]. DSSC yang menggunakan dye sintesis seperti Ruthenium Complex memiliki stabilitas yang lebih lama dibandingkan dengan dye organik yang mudah terdegradasi ${ }^{[13]}$.

Seiring dengan berjalannya waktu, larutan elektrolit pada DSSC akan semakin berkurang sehingga mempengaruhi efisisensinya. Oleh karena itu, pada penelitian ini dilakukan karakterisasi $I-V$ selama 21 hari dengan selang 7 hari untuk mengetahui kestabilan DSSC dengan variasi jarak elektroda.

\section{METODE}

Kaca Fluoride-doped Thin Oxide (FTO) digunakan sebagai substrat untuk elektroda kerja dan elektroda lawan. Substrat yang digunakan sebagai elektroda lawan, diberi lubang sebagai masuknya larutan elektrolit dengan cara dibor. Substrat dibersihkan menggunakan ultrasonic cleaner selama 10 menit. Lapisan semikonduktor menggunakan pasta $\mathrm{TiO}_{2}$ transparan. Pasta $\mathrm{TiO}_{2}$ transparan diencerkan menggunakan etanol dengan perbandingan 1 gram: $1 \mathrm{ml}$ kemudian diaduk dengan magnetic stirrer. $\mathrm{TiO}_{2}$ dideposisi pada sisi konduktif kaca FTO dengan luasan aktif $0,5 \mathrm{~cm} \times 1 \mathrm{~cm}$ menggunakan metode screen printing. Elektroda kerja di drying menggunakan hotplate pada suhu $130^{\circ} \mathrm{C}$ selama 10 menit, kemudian dideposisi kembali hingga 3 lapis dan di annealing pada suhu $500{ }^{\circ} \mathrm{C}$. Dye yang digunakan adalah Dye Ruthenium Complex N719. Elektroda kerja direndam dalam dye selama 24 jam.

Elektroda lawan dibuat dari platina cair yang dideposisi pada substrat menggunakan metode brush painting kemudian di drying menggunakan hotplate pada suhu $250{ }^{\circ} \mathrm{C}$ selama 10 menit. Larutan elektrolit terdiri dari campuran potassium iodide (KI), poly ethylene glycol (PEG) 400, and iodine $\left(\mathrm{I}_{2}\right)$. Larutan pertama dibuat dari $10 \mathrm{ml}$ PEG dan 0,8 gram KI. Larutan kedua dibuat dari 0,127 gram $\mathrm{I}_{2}$ dan $10 \mathrm{ml}$ PEG. Kedua larutan tersebut dicampur dan diaduk menggunakan magnetic strirrer selama ${ }^{[14]}$.

Elektroda lawan diberi spacer (jarak elektroda) yang memiliki ketebalan $76 \mu \mathrm{m}$ dan 114 $\mu \mathrm{m}$ pada sisi yang tidak terdeposisi platina. Kedua elektroda disusun menggunakan struktur sandwich dan disuntikan larutan elektrolit melalui lubang pada elektroda lawan. DSSC dikarakterisasi menggunakan Keithley I-V Meter dengan penyinaran $1000 \mathrm{~W} / \mathrm{m}^{2}$ oleh lampu Xenon pada kondisi terang. Karakterisasi $I-V$ dilakukan selama 21 hari dengan selang 7 hari. Hal ini bertujuan untuk mengetahui kestabilan dari DSSC dengan variasi jarak elektroda berdasarkan selang waktu pengukuran. 


\section{HASIL DAN PEMBAHASAN}

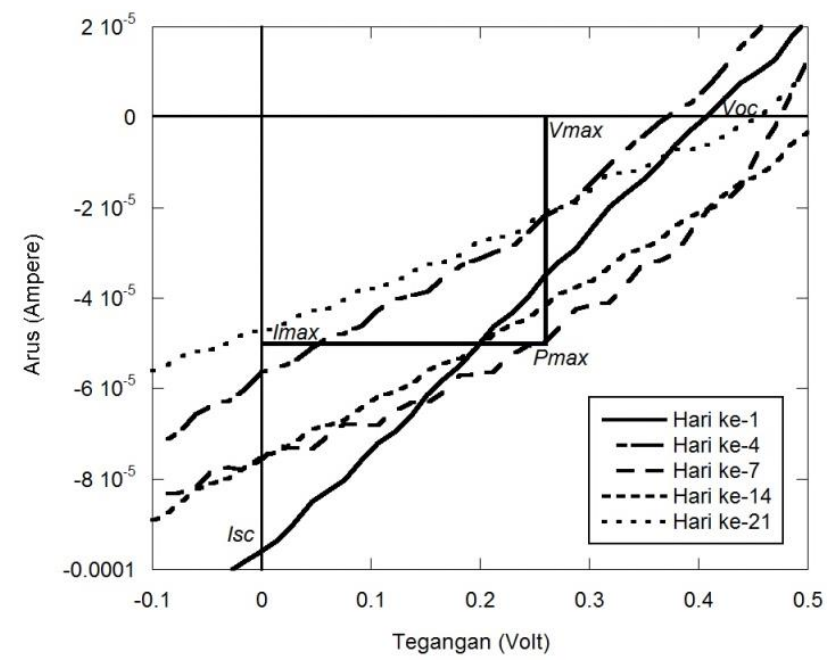

(a)

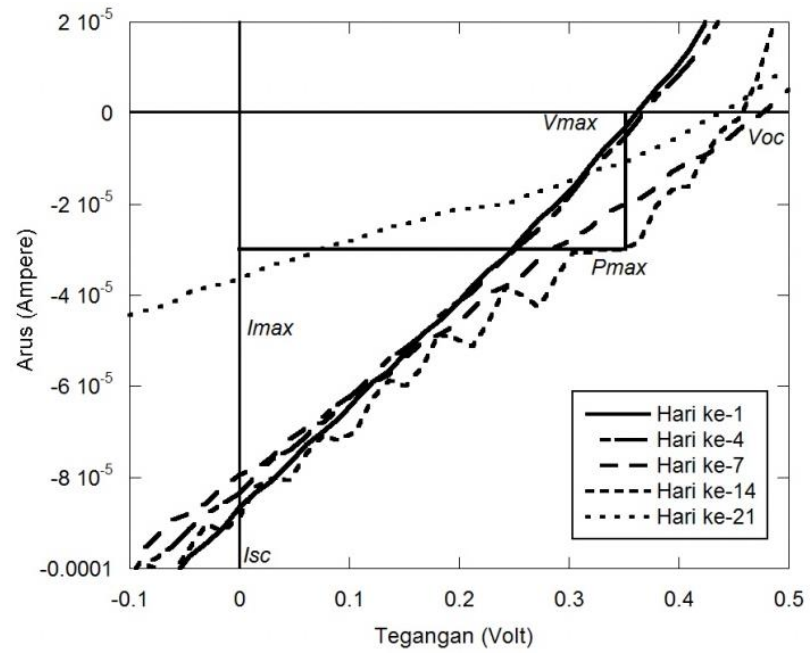

(b)

Gambar 1. Kurva I-V DSSC dengan waktu pengukuran 1,7,14 dan 21 hari (a) jarak elektroda $76 \mu \mathrm{m}$ (b) jarak elektroda $114 \mu \mathrm{m}$

Semakin besar jarak elektroda DSSC, maka semakin banyak larutan elektrolit sehingga kestabilan DSSC semakin panjang. Pada penelitian ini terlihat bahwa DSSC dengan jarak elektroda $114 \mu \mathrm{m}$ memiliki kestabilan yang lebih panjang. Pada karakterisasi $I-V$ hari ke1, efisiensi DSSC dengan jarak elektroda $114 \mu \mathrm{m}$ sangat kecil dikarenakan jumlah elektrolit yang terlalu banyak. Waktu pengukuran DSSC mempengaruhi efisiensi karena seiring dengan berjalannya waktu, larutan elektrolit akan semakin berkurang karena menguap. Efisiensi DSC dengan jarak elektroda $114 \mu \mathrm{m}$ semakin meningkat seiring dengan berkurangnya larutan elektrolit hingga mencapai jumlah optimum dan mulai mengalami penurunan pada hari ke-21. 
Tabel 1. Parameter-parameter DSSC dengan Jarak Elektroda $76 \mu \mathrm{m}$

\begin{tabular}{cccccccc}
\hline Hari ke- & $V_{o c}(\mathrm{~V})$ & $\begin{array}{c}I_{s c}(\mathrm{~A}) \\
\left(10^{-5}\right)\end{array}$ & $V_{\max }(\mathrm{V})$ & $\begin{array}{c}I_{\max }(\mathrm{A}) \\
\left(10^{-5}\right)\end{array}$ & $\begin{array}{c}P_{\max }(\mathrm{Watt}) \\
\left(10^{-5}\right)\end{array}$ & $F F$ & $\begin{array}{c}\eta(\%) \\
\left(10^{-2}\right)\end{array}$ \\
\hline \multirow{2}{*}{$\begin{array}{c}1 \\
7\end{array}$} & 0,40 & 10,00 & 0,23 & 4,91 & 0,11 & 0,29 & 2,31 \\
14 & 0,44 & 6,22 & 0,32 & 5,34 & 1,74 & 0,62 & 3,47 \\
21 & 0,47 & 7,59 & 0,31 & 4,09 & 1,27 & 0,35 & 2,53 \\
\hline
\end{tabular}

Dari Gambar 1a diperoleh beberapa parameter DSSC yang ditunjukkan oleh Tabel 1. Efisiensi DSSC dengan jarak elektroda 76 meningkat pada hari ke-7 kemudian turun hingga hari ke-21 yang disebabkan oleh mengeringnya larutan elektrolit. Berdasarkan Tabel 1 DSSC dengan jarak elektroda $76 \mu \mathrm{m}$ stabil hingga hari ke-7 dengan efisiensi $0,0347 \%$.

Tabel 2. Parameter-parameter DSSC dengan Jarak Elektroda $114 \mu \mathrm{m}$

\begin{tabular}{|c|c|c|c|c|c|c|c|}
\hline Hari ke- & $V_{o c}(\mathrm{~V})$ & $\begin{array}{l}I_{s c}(\mathrm{~A}) \\
\left(10^{-5}\right) \\
\end{array}$ & $V_{\max }(\mathrm{V})$ & $\begin{array}{c}I_{\max }(\mathrm{A}) \\
\left(10^{-5}\right) \\
\end{array}$ & $\begin{array}{c}P_{\max }(\text { Watt }) \\
\left(10^{-5}\right) \\
\end{array}$ & $F F$ & $\begin{array}{l}\eta(\%) \\
\left(10^{-2}\right) \\
\end{array}$ \\
\hline 1 & 0,35 & 7,94 & 0,19 & 4,87 & 0,92 & 0,32 & 1,85 \\
\hline 7 & 0,44 & 8,05 & 0,25 & 4,23 & 1,06 & 0,29 & 2,11 \\
\hline 14 & 0,37 & 7,46 & 0,35 & 5,58 & 1,98 & 0,71 & 3,96 \\
\hline 21 & 0,41 & 3,73 & 0,25 & 2,35 & 0,58 & 0,37 & 1,17 \\
\hline
\end{tabular}

Dari Gambar 1b diperoleh beberapa parameter DSSC yang ditunjukkan oleh Tabel 2. Berdasarkan Tabel 2 terlihat bahwa efisiensi terbesar DSSC dengan jarak elektroda 114 $\mu \mathrm{m}$ adalah 0,0396\% pada hari ke-14. Efisiensi DSSC terus meningkat dari hari ke-7 hingga hari ke-14. Hal ini menunjukkan bahwa DSSC dengan jarak elektroda $114 \mu \mathrm{m}$ stabil hingga hari ke-14.

\section{KESIMPULAN}

Penelitian tentang pengaruh selang waktu pengukuran terhadap efisiensi DSSC telah dilakukan. Efisiensi tertinggi pada pengujian hari ke-1 dan ke-7 ada pada DSSC dengan jarak elektroda $76 \mu \mathrm{m}$ dengan efisiensi $0,0231 \%$ dan $0,0347 \%$, hari ke-14 dan ke-21 ada pada $114 \mu \mathrm{m}$ dengan efisiensi $0,0396 \%$ dan $0,0117 \%$.

\section{UCAPAN TERIMAKASIH}

Penulis mengucapkan terimakasih kepada Higher Education and Institute for Research and Community services, Universitas Sebelas Maret atas pendanaan hibah penelitian PU UNS. (Nomor Kontrak: 1075/UN27.21/PP/2017). 


\section{REFERENSI}

1 Sentil, R.A., Theerthagiri, J., Madhavan, J., Ganesan, S., \& Arof, A.K. 2017. Influence of organic additive to PVDF-HFP mixed iodide electrolytes on the photovoltaic performance of dye-sensitized solar cells. Journal of Physics and Chemistry of Solids, 101, $18-24$.

2 Kagaku \& Sumitomo. 2010. Development of Next Generation Organic Solar Cell. Japan: Sumitomo Chemical Co, Ltd.

3 Wang, Y.C., \& Cho, C.P. 2017. Application of TiO-graphene nanocomposites to photoanode of dye-sensitized solar cell. Journal of Photochemistry and Photobiology A: Chemistry, 332, 1-9.

4 Li, K., Wang, Y., Sun, Y., \& Yuan, C. 2010. Preparation of nanocrystalline $\mathrm{TiO}_{2}$ electrode by layer-by-layer screen printing and its application in dye-sensitized solar cell. Materials Science and Engineering B, 175 (1), 44-47.

$5 \mathrm{Wu}$, C., Chen, B., Zheng, X., \& Priya, S. 2016. Scaling of the flexible dye sensitized solar cell module. Solar Energy Materials \& Solar Cells, 157, 438-446.

6 Ertenela, S., Ocakoglu, K., Tarnowska A., Vakuliuk, A., \& Gryko, D.T. 2015. Performance of zinc chlorophyll based molecules for dye sensitized solar cell. Dyes and Pigments, 114, 129-137.

7 Jalali, M., Moakhar, R.S., Kushwaha, A., Goh, G.K.L., Riahinoori, N., \& Sadrnezhaad, S.K. 2015. Enhanced dye loading-light harvesting $\mathrm{TiO}_{2}$ photoanode with screen printed nanorod-nanoparticles assembly for highly efficient solar cell. Electrochimica Acta, 169, 295-401.

8 Wu, J., Lan, Z., Hao, S., Li, P., Lin, J., Huang, M., Fang, L., \& Huang, Y. 2008. Progress on the electrolytes for dye-sensitized solar cells. Pure and Applied Chemistry, 80, 2241-2258.

9 Bahramian, A., \& Vashaee, D. 2015. In-situ fabricated transparent conducting nanofiber shape polyaniline/coral-like $\mathrm{TiO}_{2}$ thin film: Application in bifacial dye-sensitized solar cells. Solar Energy Materials \& Solar Cells, 143, 284-295.

10 Chen, L., Tan, W., Zhang, J., Zhou, X., Zhang, X., \& Lin, Y. 2010. Fabrication of high performance $\mathrm{Pt}$ counter electrodes on conductive plastic substrate for flexible dyesensitized solar cells. Electrochimica Acta, 55, 3721-3726.

11 Alwani, M.A., Mohamad, A.B., Ludin, N.A., Kadhum, A.A., \& Sopian, K. 2016. Dye sensitised solar cells: Development, structure, operation principles, electron kinetics, characterisation, synthesis materials and natural photosensitisers. Renewable and Sustainable Energy Reviews, 65, 183-215.

12 Pratiwi, D., Nurosyid, F., Supriyanto, A., \& Suryana, R. 2016. Optical properties of natural dyes on the dye-sensitized solar cells (DSSC) performance. Journal of Physics: Conference Series, 776 (1).

13 Mahalingam, S., \& Abdullah, H. 2016. Electron transport study of indium oxide as photoanode in DSSCs: A review. Renewable and Sustainable Energy, 63, 245-255.

14 Hardani., H., Darmawan, M.I., \& Supriyanto, A. 2016. Pengaruh Konsentrasi Ruthenium (N719) sebagai Fotosensitizer dalam Dye-Sensitized Solar Cells (DSSC) Transparan. Jurnal Fisika dan Aplikasinya, 12 (3), 104-108. 